\title{
Leaching of Polymetallic Cu-Zn-Pb Concentrate with Sodium Nitrate in Sulphuric Acid
}

\author{
MIROSLAV D. SOKIĆ, Institute for Technology of Nuclear \\ and Other Mineral Raw Materials, Belgrade \\ BRANISLAV R. MARKOVIĆ, Institute for Technology of Nuclear \\ and Other Mineral Raw Materials, Belgrade \\ $D U \check{S} A N$ V . MILOJKOV, Institute for Technology of Nuclear \\ and Other Mineral Raw Materials, Belgrade \\ ALEKSANDRA S. PATARIĆ, Institute for Technology of Nuclear \\ and Other Mineral Raw Materials, Belgrade \\ MLADEN D. BUGARČIĆ, Institute for Technology of Nuclear \\ and Other Mineral Raw Materials, Belgrade \\ GVOZDEN B. JOVANOVIĆ, Institute for Technology of Nuclear \\ and Other Mineral Raw Materials, Belgrade \\ KATARINA R. PANTOVIĆ-SPAJIĆ, Institute for Technology of Nuclear \\ and Other Mineral Raw Materials, Belgrade
}

The results of polymetallic sulphide $\mathrm{Cu}-\mathrm{Zn}-\mathrm{Pb}$ concentrate leaching with sulphuric acid in the presence of sodium nitrate as an oxidizing agent, at atmospheric pressure, are presented and discussed. Chemical composition and phase ratio of the starting concentrate and solid residuals after the leaching process are shown. Chemical reactions of leaching and their thermodynamic probabilities are predicted based on the calculated Gibbs energies and analysis of E-pH diagrams. The influence of temperature and time on the leaching degree of the concentrate's components is experimentally determined. It is shown that it is possible to obtain copper, zinc and iron in a solute form, while lead in the anglesite $\left(\mathrm{PbSO}_{4}\right)$ form remains in the solid residual after the leaching process. The iron is being oxidized to Fe(III)-sulphate, which takes part in a sulphide leached minerals and turns into $\mathrm{Fe}(\mathrm{II})$-sulphate.

Key words: polymetallic $\mathrm{Cu}-\mathrm{Zn}-\mathrm{Pb}$ concentrate, leaching, sodium nitrate, sulphuric acid

\section{INTRODUCTION}

Non-ferrous metals and iron usually appears in a form of sulphide complex ores. Large deposits of complex ores often contain chalcopyrite, sphalerite, galena and pyrite, which are fine-grained structures complexly fused with tailings minerals in complex mineral forms [1]. Sometimes, when it is difficult to prepare flotation concentrates of the individual minerals, then it is easier to prepare bulk concentrates [2]. Although

Author's address: Miroslav Sokić, Institute for Technology of Nuclear and Other Mineral Raw Materials, Belgrade, Franse d'Eperea 86

e-mail: m.sokic@itnms.ac.rs

Paper received: 12.08.2021.

Paper accepted: 16.08.2021. treatments by pyrometallurgical process are not attractive, because a large amounts of $\mathrm{SO}_{2}$ is produced, approximatelly $80-85 \%$ of world's total copper is produced pyrometallurgically, and $80 \%$ of world's total zinc is produced by roasting-leaching-electrowinning process, and $20 \%$ is produced by Imperial Smelting Process [3-4].

Hydrometallurgical processes offer a great potetntial for treating complex sulphide ores, and it results in increased metal recoveries and reduced air pollution hazards. Recently, an increased interest is remarked related to the possible application of various reagents in a hydrometallurgical processing of sulphide concentrates. Ferric [5-11] and cupric [12, 13] ions, bacteria [14-17], and other oxidants [3, 4, 18-26] were used as oxidative leaching agents of complex sulphides in su- 
lphate and chloride media under atmospheric or extended pressure leaching conditions.

Some of the hydrometallurgical processes developed for copper ores and concentrates treatment can also be considered for a treatment of complex sulphides. The previous and current developments are discused in references $[5,14,15,18,23,24,27-44]$. The main processes and parametres are presented in Table 1.

Table 1. Hydrometallurgical processes for treatment of copper ores and concentrates

\begin{tabular}{|c|c|c|c|c|}
\hline Process & $\begin{array}{l}\text { Temperature } \\
\left({ }^{\circ} \mathrm{C}\right)\end{array}$ & $\begin{array}{l}\text { Pressure } \\
(\mathrm{atm})\end{array}$ & $\begin{array}{l}\text { Regrind D80 } \\
(\mu \mathrm{m})\end{array}$ & Special conditions \\
\hline $\begin{array}{l}\text { Activox (McDonald at al., } \\
\text { 2007; Corrans at al,. 1993; } \\
\text { Streltsova at al., 2003) }\end{array}$ & $100-110$ & $\begin{array}{l}\approx 12 \\
\mathrm{P}\left(\mathrm{O}_{2}\right) \approx 10\end{array}$ & $5-15$ & $\begin{array}{l}\text { Fine grinding combined with high oxigen overpressure } \\
\text { overcomes chalcopyrite passivation }\end{array}$ \\
\hline Albion (Hourn at al., 1999) & 85 & 1 & $5-10$ & $\begin{array}{l}\text { Atmospheric ferric leaching of very finely ground } \\
\text { concentrate }\end{array}$ \\
\hline $\begin{array}{l}\text { Anglo-American- } \\
\text { University of British } \\
\text { Columbia (McDonald at al., } \\
\text { 2007; Dreisinger, 2003; } \\
\text { Dreisinger at al., 2002) }\end{array}$ & 150 & $10-12$ & $10-15$ & $\begin{array}{l}\text { Modest regrind combined with surfacants for } \\
\text { chalcopyrite leaching }\end{array}$ \\
\hline $\begin{array}{l}\text { Bactech / Mintek low } \\
\text { temperature bioleach } \\
\text { (Miller at al., 2006) }\end{array}$ & 35 & 1 & $5-10$ & $\begin{array}{l}\text { Low T bioleach }\left(35-50^{\circ} \mathrm{C}\right) \text { requires very fine grind to } \\
\text { overcome chalcopyrite passivation }\end{array}$ \\
\hline $\begin{array}{l}\text { BIOCOP } \\
2003)\end{array}$ & $65-80$ & 1 & 37 & High $\mathrm{T}$ bioleach $\left(65-80^{\circ} \mathrm{C}\right)$ uses thermophilic bacteria \\
\hline Cymet (Kruesi at al., 1973) & $80-100$ & 1 & I & $\begin{array}{l}\text { Electrochemical dissolution in the presence of ferric } \\
\text { chloride, which finally produces copper powder }\end{array}$ \\
\hline Cyprus (Anon, 1977)) & $80-100$ & 1 & I & $\begin{array}{l}\text { Chalcopyrite concentrate leach in two-stages using a } \\
\text { mixed solution of ferric chloride and copper chloride }\end{array}$ \\
\hline $\begin{array}{l}\text { CESL copper (McDonald at } \\
\text { al., 2007; Jones, 1996) }\end{array}$ & $140-150$ & $10-12$ & 37 & $\begin{array}{l}\text { Chloride catalized leach of chalcopyrite producing basic } \\
\text { copper sulphate precipitate in the autoclave }\end{array}$ \\
\hline $\begin{array}{l}\text { Dynatec (Kofluk at al., } \\
\text { 1998; Stiksma at al., 2000) }\end{array}$ & 150 & $10-12$ & 37 & $\begin{array}{l}\text { Chalcopyrite and sphalerite is leached using low grade } \\
\text { coal as an additive }\end{array}$ \\
\hline $\begin{array}{l}\text { Minimet (Demarthe at al., } \\
\text { 1976) }\end{array}$ & $90-100$ & 1 & I & $\begin{array}{l}\text { Atmospheric cupric chloride leaching of complex } \\
\text { concentrate. To keep } \mathrm{CuCl}, \mathrm{PbCl}_{2} \text { and } \mathrm{AgCl} \text { in solution, } \\
\mathrm{NaCl} \text { was added to the leaching agent. }\end{array}$ \\
\hline $\begin{array}{l}\text { Mount Gordon (Richmond } \\
\text { at al., 2002; Dreisinger at } \\
\text { al., 2002) }\end{array}$ & 90 & 8 & 100 & $\begin{array}{l}\text { Pressure oxidation of chalcopyrite/pyrite ore or bulk } \\
\text { concentrate in an iron sulfate rich electrolite }\end{array}$ \\
\hline $\begin{array}{l}\text { NITROX (Van Weert at al., } \\
\text { 1986) }\end{array}$ & $80-100$ & 1 & I & $\begin{array}{l}\text { Atmospheric leach refractory gold ores and } \\
\text { concentrates by hot nitric acid }\end{array}$ \\
\hline $\begin{array}{l}\text { NSC (Sunshine Mine) } \\
\text { (McDonald at al., 2007; } \\
\text { Ackerman, 1990; Anderson, } \\
\text { 2003; Anderson at al., 1992, } \\
\text { 1996) }\end{array}$ & $130-150$ & $7 \mathrm{P}\left(\mathrm{O}_{2}\right) \approx 4$ & 10 & $\begin{array}{l}\text { Nitrite catalized leach of chalcopyrite by sulphuric acid } \\
\text { leaching agent containing cupri and feri chloride with } \\
\text { oxigen pressure }\end{array}$ \\
\hline $\begin{array}{l}\text { PLATSOL (Fleming at al., } \\
\text { 2001) }\end{array}$ & $220-230$ & $30-40$ & 15 & $\begin{array}{l}\text { Total pressure oxidation in the presence of } 10-20 \mathrm{~g} / \mathrm{dm}^{3} \\
\mathrm{NaCl} \text {. Precious metals leached at the same time as base } \\
\text { metals }\end{array}$ \\
\hline $\begin{array}{l}\text { Sepon copper (Baxter at al., } \\
\text { 1978) }\end{array}$ & $\begin{array}{l}\text { 80-Copper } \\
220-230- \\
\text { Pyrite }\end{array}$ & $\begin{array}{l}\text { Atm } \\
30-40\end{array}$ & $\begin{array}{l}100 \\
50\end{array}$ & $\begin{array}{l}\text { Atmospheric ferric leach for copper from chalcocite. } \\
\text { Pressure oxidation of pyrite concentrate to make acid } \\
\text { and ferric sulphate for copper leach }\end{array}$ \\
\hline $\begin{array}{l}\text { Sherritt-Cominco (Swinkels } \\
\text { at al., 1978) }\end{array}$ & $\approx 150$ & $\begin{array}{l}\approx 25 \\
\mathrm{P}\left(\mathrm{O}_{2}\right) \approx 10\end{array}$ & I & $\begin{array}{l}\text { A two-stage process starting with the removal of } \\
\text { sulphur and iron from low grade } \mathrm{Cu} \text { concentrate. Than a } \\
\text { high-grade } \mathrm{Cu} \text { concentrate leach by sulphuric acid } \\
\text { under oxigen pressure }\end{array}$ \\
\hline $\begin{array}{l}\text { Sherritt-Gordon (Bolton at } \\
\text { al., 1979) }\end{array}$ & 150 & $\mathrm{P}\left(\mathrm{O}_{2}\right) \approx 3.5$ & 44 & $\begin{array}{l}\text { Oxigen pressure oxidation complex concentrate. Copper } \\
\text { and zinc go into solution, lead is transformed into } \\
\mathrm{PbSO}_{4} \text { and lead jarosite and is retained in the residue }\end{array}$ \\
\hline $\begin{array}{l}\text { Total pressure oxidation } \\
\text { (McDonald at al., 2007; } \\
\text { King at al., 1995; Marsden } \\
\text { at al., 2003) }\end{array}$ & $200-230$ & $\begin{array}{l}30-40 \\
\mathrm{P}\left(\mathrm{O}_{2}\right) \approx 7\end{array}$ & 37 & $\begin{array}{l}\text { Extreme conditions of } \mathrm{T} \text { and } \mathrm{P} \text { designed to rapidly } \\
\text { destroy refractory gold ores and concentrates in the } \\
\text { presence of } \mathrm{NaCl} \text { in the leaching agent }\end{array}$ \\
\hline
\end{tabular}


Much attention has been given to the development of nitric acid based processes for sulphide ores and concentrates, e.g. Habashi discuss that metal sulphide oxidation by nitric acid can be achieved in two ways [45]. In the first case, $\mathrm{NO}_{3}^{-}$ion is oxidant, and during the reaction it is reduced to $\mathrm{NO}$ or $\mathrm{NO}_{2}$. In the second case, oxygen which arises from nitric acid decom-position is the oxidant.

Van Weert et al. [46] developed the NITROX process, which utilizes nitric acid to recover gold from refractory pyrite and arsenopyrite ores. They found that sulphide sulphur formed mainly elemental sulphur, while smaller part formed sulphate. The NO gas that is produced is directly oxidized by the air into the $\mathrm{NO}_{2}$, which dissolves in the solution and reacts with water to form $\mathrm{HNO}_{3}$, thereby completing the NITROX cicle. The most significant problem was high sulphate production. Droppert and Shang [47] showed that sulphate formation could be minimized by addi-tion of a small excess of $\mathrm{HNO}_{3}$, followed by slow addition of $\mathrm{HNO}_{3}$ keeping the acid concentration at a constant low level.

Some industrial operations use the nitric or nitrous acid added in a small concentration to the sulphuric acid, e.g. in oxigen extended pressure leach processes. At Sunshine Precious Metals, silver and copper are recovered from a complex sulphide concentrate at temperatures between $145^{\circ}$ and $155^{\circ} \mathrm{C}$ and at total pressure of $709 \mathrm{kPa}[24,39,48]$. In that case, nitrous acid were found to enhance the solubilization of minerals at lower temperatures and pressures, and the nitrous/sulphuric acid leach process is used with success.

Following successful operation in the Sunshine Pressure Leach plant, the catalysis under the extended pressure oxidation, using nitrogen species, is promoted as a nitrogen species catalised (NSC) technology [23, 48]. It was demonstrated that the addition of nitrite ion in a small amounts catalyses the oxidation of sulfides in the presence of oxigen; recent data show that it is a fast reaction, typicaly less than $30 \mathrm{~min}$, for slurry containing $100 \mathrm{~g} / \mathrm{L}$ of solids [23]. The leaching process of metal sulphides by nitric acid as oxidant is more efficient in presence of $\mathrm{NO}^{+}$ions. The addition of $\mathrm{NO}^{2-}$ ions instead of $\mathrm{NO}^{3-}$ ions accelerates the formation of $\mathrm{NO}^{+}$ions, which further oxidises sulphide minerals at lower temperatures to the elemental sulfur [40, 48].

Oxidative dissolution of a sulphide concentrate using nitrate as the leaching agent in an acid medium take place with formation of elemental sulphur, and it can be reperesented by one of the following chemical reactions [20, 21, 49]:

$$
\begin{aligned}
& 3 \mathrm{MeS}+2 \mathrm{NO}_{3}+8 \mathrm{H}^{+}= \\
& =3 \mathrm{Me}^{2+}+3 \mathrm{~S}^{0}+2 \mathrm{NO}+4 \mathrm{H}_{2} \mathrm{O}
\end{aligned}
$$

or

$$
\begin{aligned}
& \mathrm{MeS}+2 \mathrm{NO}_{3}{ }^{-}+4 \mathrm{H}^{+}= \\
& =\mathrm{Me}^{2+}+\mathrm{S}^{0}+2 \mathrm{NO}_{2}+2 \mathrm{H}_{2} \mathrm{O}
\end{aligned}
$$

Initially the rate of reaction is controled by a surface chemical reaction and later on changes into a diffusion controled.

General flow sheet for the treatment for the complex $\mathrm{Cu}-\mathrm{Zn}-\mathrm{Pb}$ concentrates is presented in Fig 1 .

The objactive of this work is performance of the leaching process using the selected complex $\mathrm{Cu}-\mathrm{Zn}-\mathrm{Pb}$ sulphide concentrates, from "Rudnik" flotation plant, by sulphuric acid solution in the presence of sodium nitrate.

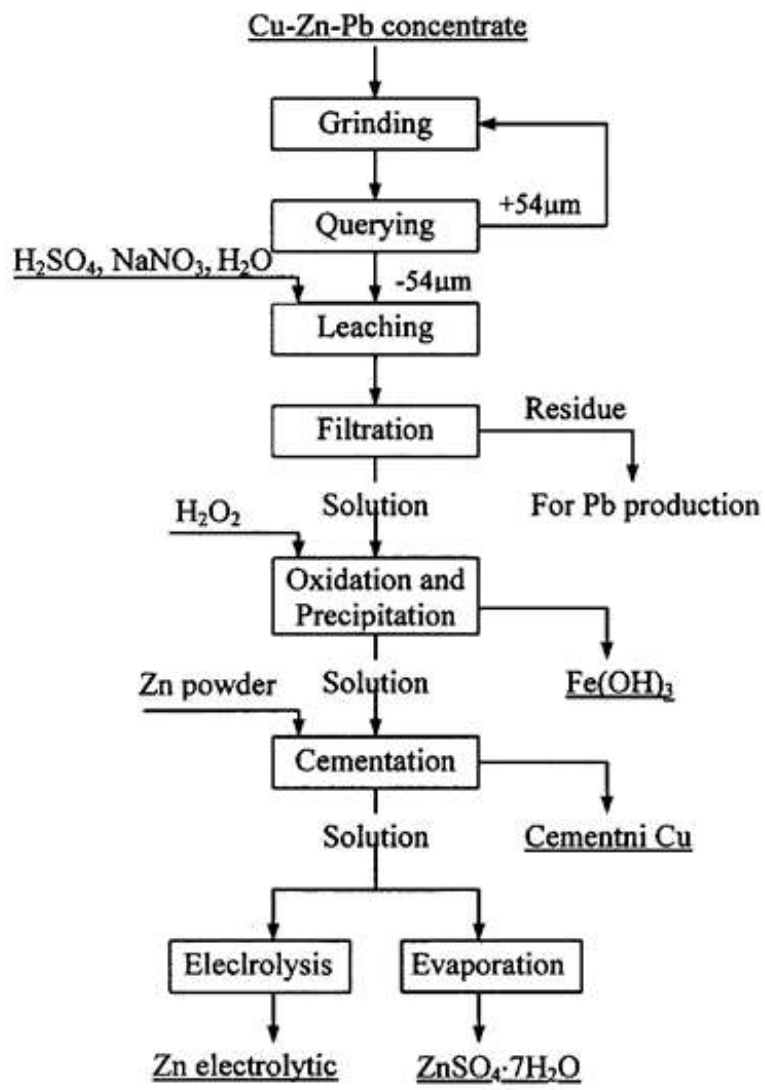

Figure 1 - General flow sheet for the treatment of the complex $\mathrm{Cu}-\mathrm{Zn}$-Pb concentrates

\section{CHEMICAL REACTIONS AND THERMODYNAMICS}

Based on the literature data and on the characterization of both produced solution and leaching solid residues, obtained by leaching of pollymetalic concentrate containing chalcopyrite, sphalerite, galena and pyrrhotite in oxidized acidic medium, following chemical reactions were chosen in this study and than analyzed in the $\mathrm{H}_{2} \mathrm{SO}_{4}-\mathrm{NaNO}_{3}-\mathrm{H}_{2} \mathrm{O}$ system.

Chalcopyrite $\left(\mathrm{CuFeS}_{2}\right)$ leaching system 


$$
\begin{aligned}
& \mathrm{CuFeS}+4 / 3 \mathrm{NaNO}_{3}+8 / 3 \mathrm{H}_{2} \mathrm{SO}_{4}= \\
&=\mathrm{CuSO} \mathrm{S}_{4}+\mathrm{FeSO}_{4}+2 / 3 \mathrm{Na}_{2} \mathrm{SO}_{4}+2 \mathrm{~S}^{0}+ \\
&+4 / 3 \mathrm{NO}+8 / 3 \mathrm{H}_{2} \mathrm{O} \\
& \mathrm{CuFeS}_{2}+4 \mathrm{NaNO}_{3}+4 \mathrm{H}_{2} \mathrm{SO}_{4}= \\
&= \mathrm{CuSO} \\
& 4+\mathrm{FeSO}_{4}+2 \mathrm{Na}_{2} \mathrm{SO}_{4}+2 \mathrm{~S}^{0}+4 \mathrm{NO}_{2}+4 \mathrm{H}_{2} \mathrm{O} \\
& \mathrm{CuFeS}_{2}+5 / 3 \mathrm{NaNO}_{3}+10 / 3 \mathrm{H}_{2} \mathrm{SO}_{4}= \\
&= \mathrm{OCuSO} \mathrm{C}_{4}+1 / 2 \mathrm{Fe}_{2}\left(\mathrm{SO}_{4}\right)_{3}+5 / 6 \mathrm{Na}_{2} \mathrm{SO}_{4}+ \\
&+ 2 \mathrm{~S}^{0}+5 / 3 \mathrm{NO}+10 / 3 \mathrm{H}_{2} \mathrm{O} \\
& \mathrm{CuFeS}+5 \mathrm{NaNO}_{3}+5 \mathrm{H}_{2} \mathrm{SO}_{4}= \\
&= \mathrm{CuSO} \mathrm{SO}_{4}+1 / 2 \mathrm{Fe}_{2}\left(\mathrm{SO}_{4}\right)_{3}+5 / 2 \mathrm{Na}_{2} \mathrm{SO}_{4}+ \\
&+ 2 \mathrm{~S}^{0}+5 \mathrm{NO}_{2}+5 \mathrm{H}_{2} \mathrm{O}
\end{aligned}
$$

Sphalerite $(\mathrm{ZnS})$ leaching system

$\mathrm{ZnS}+2 / 3 \mathrm{NaNO}_{3}+4 / 3 \mathrm{H}_{2} \mathrm{SO}_{4}=$

$=\mathrm{ZnSO}_{4}+1 / 3 \mathrm{Na}_{2} \mathrm{SO}_{4}+\mathrm{S}+2 / 3 \mathrm{NO}+4 / 3 \mathrm{H}_{2} \mathrm{O}$

$\mathrm{ZnS}+2 \mathrm{NaNO}_{3}+2 \mathrm{H}_{2} \mathrm{SO}_{4}=$

$=\mathrm{ZnSO}_{4}+\mathrm{Na}_{2} \mathrm{SO}_{4}+\mathrm{S}+2 \mathrm{NO}_{2}+2 \mathrm{H}_{2} \mathrm{O}$

Galenite $(\mathrm{PbS})$ leaching system

$\mathrm{PbS}+2 / 3 \mathrm{NaNO}_{3}+4 / 3 \mathrm{H}_{2} \mathrm{SO}_{4}=$

$=\mathrm{PbSO}_{4}+1 / 3 \mathrm{Na}_{2} \mathrm{SO}_{4}+\mathrm{S}+2 / 3 \mathrm{NO}+4 / 3 \mathrm{H}_{2} \mathrm{O}$

$\mathrm{PbS}+2 \mathrm{NaNO}_{3}+2 \mathrm{H}_{2} \mathrm{SO}_{4}=$

$=\mathrm{PbSO}_{4}+\mathrm{Na}_{2} \mathrm{SO}_{4}+\mathrm{S}+2 \mathrm{NO}_{2}+2 \mathrm{H}_{2} \mathrm{O}$

Pirrhotite $\left(\mathrm{Fe}_{x-1} \mathrm{~S}_{x}\right)$ leaching system

$(1 / x-1) \mathrm{Fe}_{x-1} \mathrm{~S}_{x}+4 / 3 \mathrm{H}_{2} \mathrm{SO}_{4}+2 / 3 \mathrm{NaNO}_{3}=$

$=\mathrm{FeSO}_{4}+1 / 3 \mathrm{Na}_{2} \mathrm{SO}_{4}+(x / x-1) \mathrm{S}+2 / 3 \mathrm{NO}+4 / 3 \mathrm{H}_{2} \mathrm{O}$

$(1 / x-1) \mathrm{Fe}_{x-1} \mathrm{~S}_{x}+2 \mathrm{H}_{2} \mathrm{SO}_{4}+2 \mathrm{NaNO}_{3}=$

$=\mathrm{FeSO}_{4}+\mathrm{Na}_{2} \mathrm{SO}_{4}+(x / x-1) \mathrm{S}+2 \mathrm{NO}_{2}+2 \mathrm{H}_{2} \mathrm{O}$

$(1 / x-1) \mathrm{Fe}_{x-1} \mathrm{~S}_{x}+2 \mathrm{H}_{2} \mathrm{SO}_{4}+\mathrm{NaNO}_{3}=1 / 2 \mathrm{Fe}_{2}\left(\mathrm{SO}_{4}\right)_{3}+$

$+1 / 2 \mathrm{Na}_{2} \mathrm{SO}_{4}+(x / x-1) \mathrm{S}+\mathrm{NO}+2 \mathrm{H}_{2} \mathrm{O}$

$(1 / x-1) \mathrm{Fe}_{x-1} \mathrm{~S}_{x}+3 \mathrm{H}_{2} \mathrm{SO}_{4}+3 \mathrm{NaNO}_{3}=1 / 2 \mathrm{Fe}_{2}\left(\mathrm{SO}_{4}\right)_{3}+$

$+3 / 2 \mathrm{Na}_{2} \mathrm{SO}_{4}+(x / x-1) \mathrm{S}+3 \mathrm{NO}_{2}+3 \mathrm{H}_{2} \mathrm{O}$

Thermodynamic analysis included calculation of standard Gibbs energy change and E-pH diagrams. In order to clarify the occurrence probability of quoted reactions (3)-(14), Gibbs energy change was calculated within a temperature range of 25 up-to $90^{\circ} \mathrm{C}$ and the obtained values are given in Table 2.

Table 2. The calculated values of standard Gibbs energy change at temperatures 298 and $363 \mathrm{~K}$ (HSC) of the analised reactions in the pollymetalic concentrate $-\mathrm{H}_{2} \mathrm{SO}_{4}-\mathrm{NaNO}_{3}-\mathrm{H}_{2} \mathrm{O}$ system

\begin{tabular}{|l|l|l|l|l|l|}
\hline $\begin{array}{l}\text { Eq. } \\
\text { no. }\end{array}$ & $\begin{array}{l}\Delta \mathrm{G}^{\mathrm{o}}{ }_{298} \\
(\mathrm{~kJ} / \mathrm{mol})\end{array}$ & $\begin{array}{l}\Delta \mathrm{G}_{363}^{\mathrm{o}} \\
(\mathrm{kJ} / \mathrm{mol})\end{array}$ & $\begin{array}{l}\mathrm{Eq} . \\
\text { no. }\end{array}$ & $\begin{array}{l}\Delta \mathrm{G}_{298} \\
(\mathrm{~kJ} / \mathrm{mol})\end{array}$ & $\begin{array}{l}\Delta \mathrm{G}_{363} \\
(\mathrm{~kJ} / \mathrm{mol})\end{array}$ \\
\hline$(3)$ & -330.978 & -341.369 & $(9)$ & -236.464 & -241.964 \\
\hline$(4)$ & -352.302 & -391.600 & $(10)$ & -247.126 & -267.079 \\
\hline$(5)$ & -396.085 & -408.423 & $(11)$ & -235.312 & -240.721 \\
\hline$(6)$ & -422.741 & -471.211 & $(12)$ & -245.974 & -265.836 \\
\hline$(7)$ & -191.784 & -196.993 & $(13)$ & -300.420 & -307.775 \\
\hline$(8)$ & -202.446 & -222.108 & $(14)$ & -316.413 & -345.448 \\
\hline
\end{tabular}

HSC Chemistry software and its data base of thermodinamic values of reaction participants were used in calculations.

The negative values of Gibbs energy change $\Delta \mathrm{G}_{\mathrm{T}}$ for reactions (3)-(14) show that they are all thermodinamically feasible at standard pressure and temperature range of $30-100^{\circ} \mathrm{C}$. Higher negative $\Delta \mathrm{G}_{\mathrm{T}}$ value of the reaction (4) than that of the reaction (3) suggests its occurrence with higher thermodinamic probability. $\mathrm{NO}$ and $\mathrm{NO}_{2}$ ratio in gaseous products and elemental sulphur and sulphate ratio after leaching depend on concentration of nitrate ion (Droppert at al. 1995). E$\mathrm{pH}$ diagrams show the thermodynamic stability of water solution components and the correlations electrochemical potential - $\mathrm{pH}$ values. E-pH diagrams for the behavior of copper, zinc, lead and iron in $\mathrm{Cu}-\mathrm{Zn}$ $\mathrm{Pb}-\mathrm{Fe}-\mathrm{S}-\mathrm{H}_{2} \mathrm{O}$ system are presented in Fig. 2.
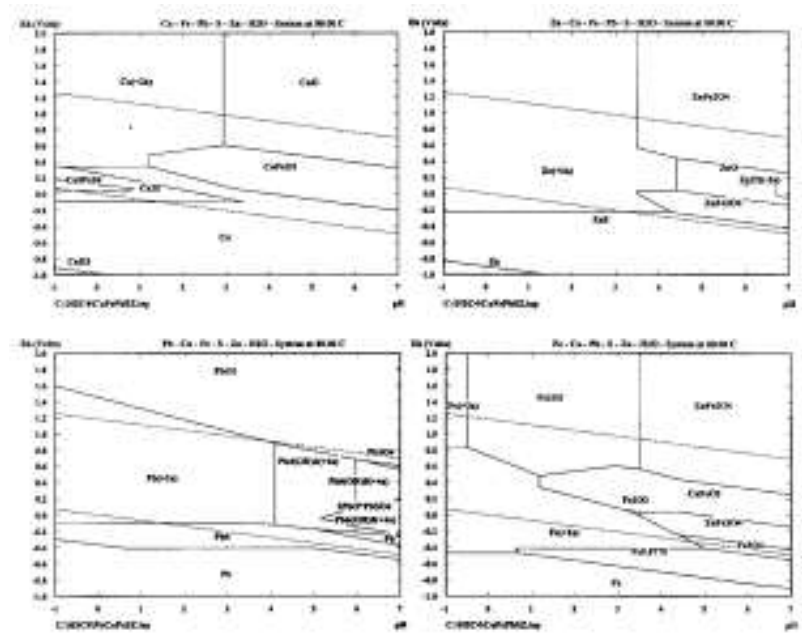

Figure 2 - E-pH diagrams for $\mathrm{Cu}-\mathrm{Zn}-\mathrm{Pb}-\mathrm{Fe}-\mathrm{S}-\mathrm{H}_{2} \mathrm{O}$ system at $80^{\circ} \mathrm{C}$

From Fig. 2 it can be concluded that copper, zinc, lead and iron leach from their minerals at low $\mathrm{pH}$ values and under the given oxidizing conditions. Under these oxidizing conditions at high electrode potential and low $\mathrm{pH}$ values, $\mathrm{Cu}^{2+}, \mathrm{Zn}^{2+}, \mathrm{Fe}^{2+}$ and $\mathrm{Fe}^{3+}$ ions exist in water solutions, while $\mathrm{Pb}^{2+}$ exists in sulphate form in the resi-due. The increase of temperature lowers the possibility of $\mathrm{Fe}^{3+}$ ion existance in the system.

\section{EXPERIMENTAL}

The concentrate enriched during the flotation of a $\mathrm{CuFeS}_{2}-\mathrm{PbS}-\mathrm{ZnS}$ polymetallic ore in the "Rudnik" flotation plant (Rudnik - Serbia) was used. All leaching experiments of polymetallic concentrate at atmospheric pressure and temperatures up-to $90^{\circ} \mathrm{C}$ were carried out using experimental set-up, which provides the stable hermetic conditions and allow the heating at constant temperature.

The liquid volume was kept co-nstant during the experiments. The calculated volumes of $\mathrm{H}_{2} \mathrm{SO}_{4}$ and 
$\mathrm{NaNO}_{3}$ solutions were put into the glass reactor and heated-up to the selected temperature. When the temperature was reached, the solid conce-ntrate was added and that moment is taken for the begi-nning of reaction.

After finite time intervals, during the leaching process, the solution samples were taken for chemical analysis which was carried out with AAS (Perkin Elmer).

The solid residues were carefully fil-tered out, washed with distilled water, dried and their phase content was determined by AAS, X-ray analysis using diffractometer (Siemens D500), light micro-scopy (Carl Zeiss-Jena JENAPOL-U) and thermal DTA / TG analysis on a NETZSH $409 \mathrm{Ep}$.

\section{RESULTS AND DISCUSSION}

\subsection{Characterization of Polymetallic Concentrate}

Chemical composition of the polymetallic concentrate, which was used in the leaching process, is presented in Table 3.

Table 3. Chemical composition of polymetallic concentrate from "Rudnik" flotation plant [50]

\begin{tabular}{|l|l|l|l|l|l|}
\hline $\mathrm{Cu}$ & $\mathrm{Zn}$ & $\mathrm{Pb}$ & $\mathrm{Fe}$ & $\mathrm{S}$ & $\mathrm{Bi}$ \\
\hline $8.92 \%$ & $8.79 \%$ & $12.66 \%$ & $19.07 \%$ & $21.02 \%$ & $0.083 \%$ \\
\hline $\mathrm{Sb}$ & $\mathrm{Cd}$ & $\mathrm{As}$ & $\mathrm{Ag}$ & $\mathrm{Au}$ & \\
\hline $0.012 \%$ & $0.065 \%$ & $0.034 \%$ & $0.021 \%$ & $0.0006 \%$ & \\
\hline
\end{tabular}

$\mathrm{X}$-ray diffraction (XRD) analysis was used for the phase fraction determination in the polymetallic concentrate; the result is shown in Figure 3.

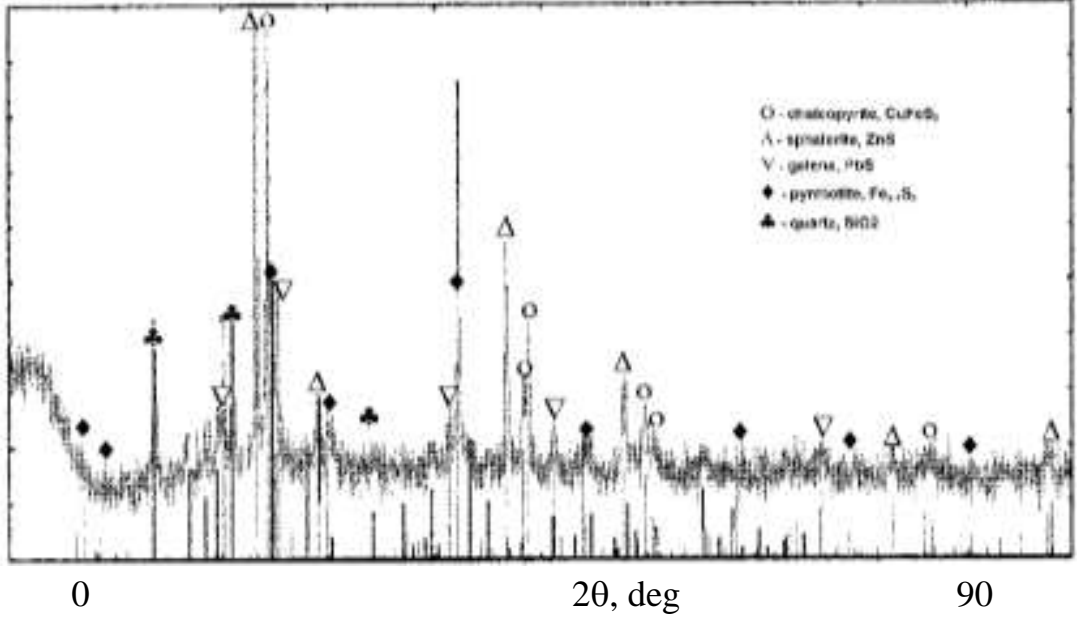

Figure 3 - X-ray diffraction (XRD) analysis of the polymetallic concentrate from "Rudnik" flotation plant [20]

The presence of chalcopyrite, sphalerite, galena, microphotograph of polyme-ta-llic concentrate from pyrrhotite and qu-artz is registered. Prepared sample „Rudnik“ flotation plant is presented in Figure 4.

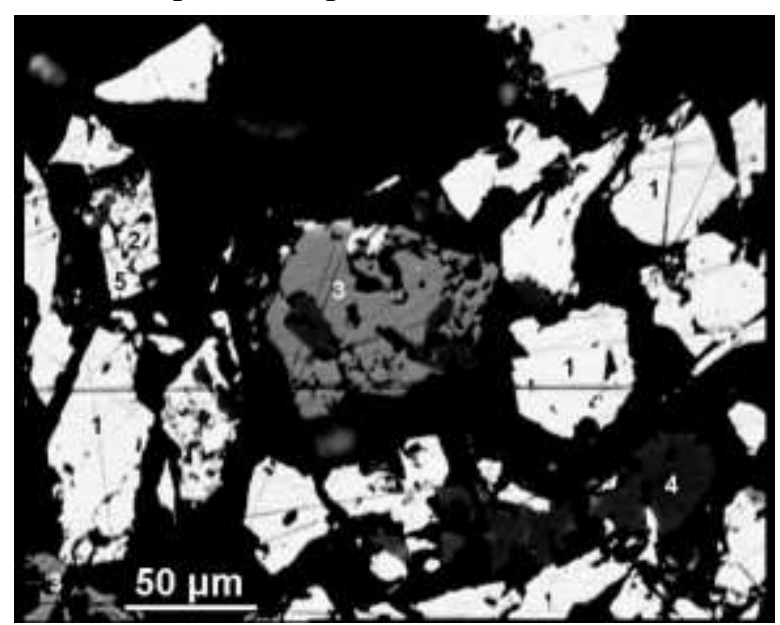

Figure 4 - Microphotograph of the polymetallic sulphide concentrate: 1-chalcopyrite, 2-pyrrhotite, 3-sphalerite, 4-quartz and 5-galena

Sulphide monominerals are predominantly irregular in shape, with dimensions in the range $10-100 \mu \mathrm{m}$. Besides, there can be observed simple and complex adherent minerals, with different combinations; mu- tually adhered beneficial minerals or minerals adhered with gangue minerals, predominantly quartz. Thermogram of polymetallic concentrate obtained at a heating rate of $10{ }^{\circ} \mathrm{C} / \mathrm{min}$ in air and shown in Figure 5 . 


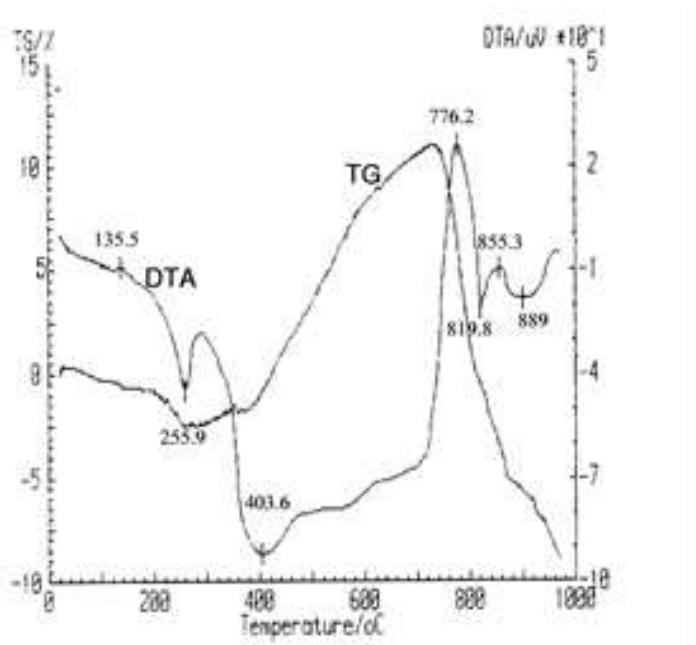

Figure 5 - DTA/TG analysis of polymetallic concentrate

When the concentrate is heated, there is an increase in mass, which is accompanied by more or less pronounced exothermic effects (up to $730^{\circ} \mathrm{C}$ ), which are the result of the presence of several types of sul- fides that oxidize differently. Further heating leads to a sudden loss of mass, which also occurs in several stages, which indicates that more different sulfates are present. These mass losses are accompanied by endothermic effects, of which they are clearly expressed at $776^{\circ} \mathrm{C}\left(\mathrm{CuSO}_{4}\right.$ dissociation $)$ and $855^{\circ} \mathrm{C}\left(\mathrm{CuSO}_{4} \cdot \mathrm{CuO}\right.$ dissociation).

\subsection{Influence of the Operating Parameters}

The experimental results on determination of leaching parameters of polymetallic concentrate from „Rudnik“ flotation plant with sulphuric acid in the presence of sodium nitrate were performed in the te-mperature range of $20-90^{\circ} \mathrm{C}$ and during the time in-tervals $60-240 \mathrm{~min}$. Further, the optimum values were: the phase ratio solid/liquid $(\mathrm{S}: \mathrm{L})=1: 5$, the starting sulphuric acid concentration $225 \mathrm{~g} / \mathrm{dm}^{3}$, the sodium nitrate content exceeds $30 \%$ of the stoichiometric calculated value.

The influences of temperature and time on the leaching degrees of the zinc, copper and iron are presented in Figure 6.
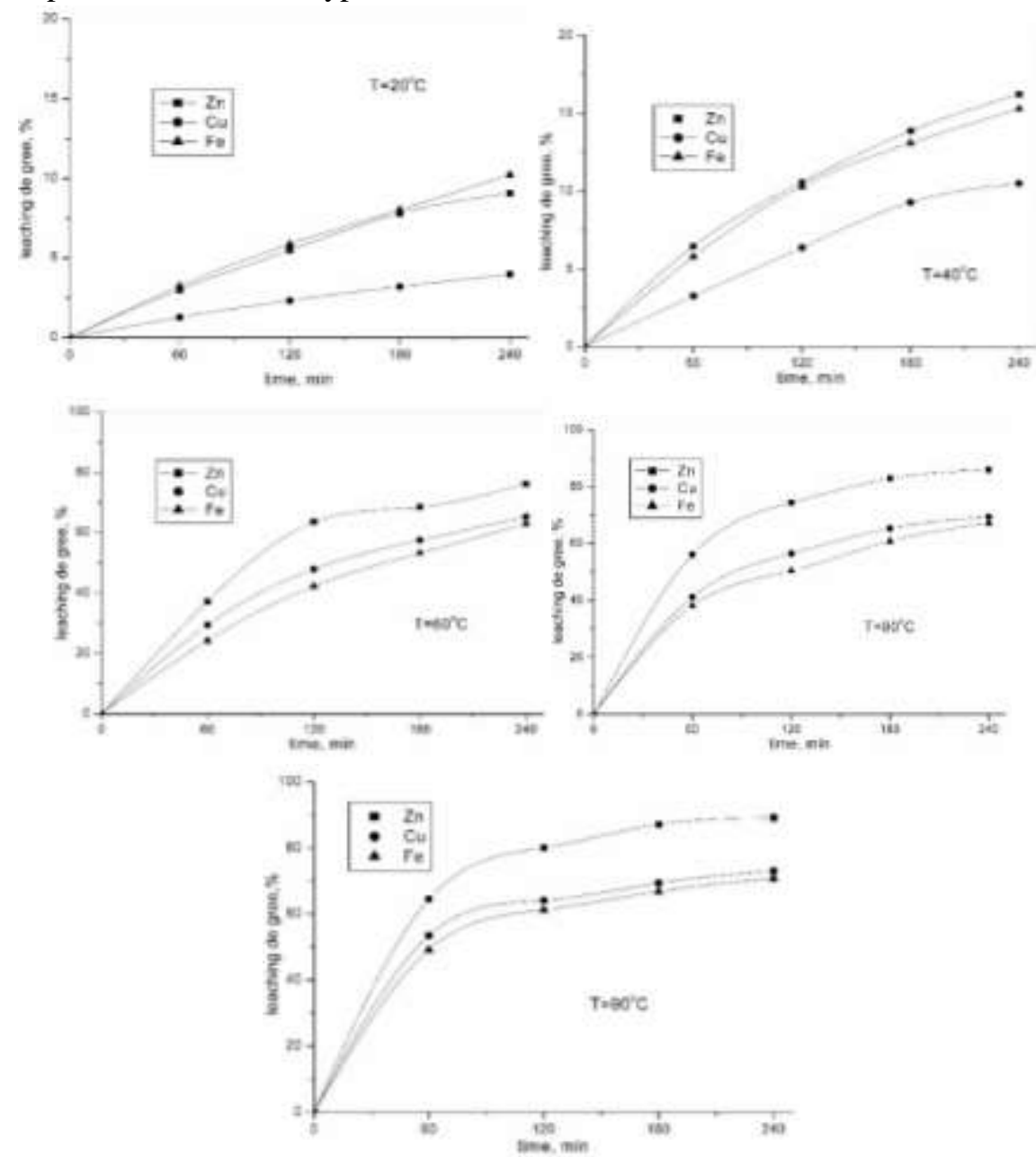

Figure 6 - Temperature and the leaching time influence on the leaching degrees: $S: L=1: 5$, the starting concentration of $\mathrm{H}_{2} \mathrm{SO}_{4}=225 \mathrm{~g} / \mathrm{dm}^{3}, \mathrm{NaNO}_{3}$ content $30 \%$ above the stoichiometrically needed, the stirring speed $300 \mathrm{r} / \mathrm{min}$ 
It is well known that the oxidative dis-solution of galena produces insoluble $\mathrm{PbSO}_{4}$ in the sulphuric acid leaching medium [51].Low leaching degree is obvious for all three metals, but for copper it is extremly low (Fig. 6.a). The similar situation occures for the influence of time on the leaching degrees at the temperature of $40^{\circ} \mathrm{C}$ (Fig. 6.b).

Onset of leaching degrees is noti-cable at the temperature of $60^{\circ} \mathrm{C}$ (Fig. 6.c), where the zinc leaching degree is the highest. Further tempe-rature increasing contributes that all three metals leac-hing degres increase (Fig. 6.d), and finally reaching the tem-perature of $90^{\circ} \mathrm{C}$ at time of $240 \mathrm{~min}$ (Fig. 6.e). It is important to notice that in contrast to the lower temperatures, when the process goes on above $50^{\circ} \mathrm{C}$ the zinc leaching degree is higher than that for iron.

\subsection{Characterization of the Solid Residuals}

Characterization of the solid residuals after the leaching process included chemical and mineralogical analyses. The samples were chosen to be representative regarding a wide range of possible leaching products. Chemical analysis of the solid residual after the leaching is presented in Table 4, as well as the overall mass of the solid residual after the leaching process.

Table 4. Chemical analysis of the solid residual: $t=90^{\circ} \mathrm{C}, \tau=240 \mathrm{~min}, S: L=1: 5$, the starting concentration of $\mathrm{H}_{2} \mathrm{SO}_{4}=225 \mathrm{~g} / \mathrm{dm}^{3}, \mathrm{NaNO}_{3}$ content $30 \%$ above the stoichiometrically needed, the stirring speed $300 \mathrm{r} / \mathrm{min}$

\begin{tabular}{|c|c|c|c|c|c|}
\hline \multirow{2}{*}{$\begin{array}{l}\text { Mass of the } \\
\text { concentrate }(\mathrm{g})\end{array}$} & \multirow{2}{*}{$\begin{array}{l}\text { Mass of the solid } \\
\text { residual }(\mathrm{g})\end{array}$} & \multicolumn{4}{|c|}{ Composition of solid residual (\%) } \\
\hline & & $\mathrm{Zn}$ & $\mathrm{Cu}$ & $\mathrm{Fe}$ & $\mathrm{Pb}$ \\
\hline 100.00 & 59.90 & 1.41 & 3.88 & 8.97 & 20.93 \\
\hline
\end{tabular}

X-ray diffraction (XRD) analysis, presented in composition of the solid residual after the leaching Fig. 7, was used for determination of the mineral process.

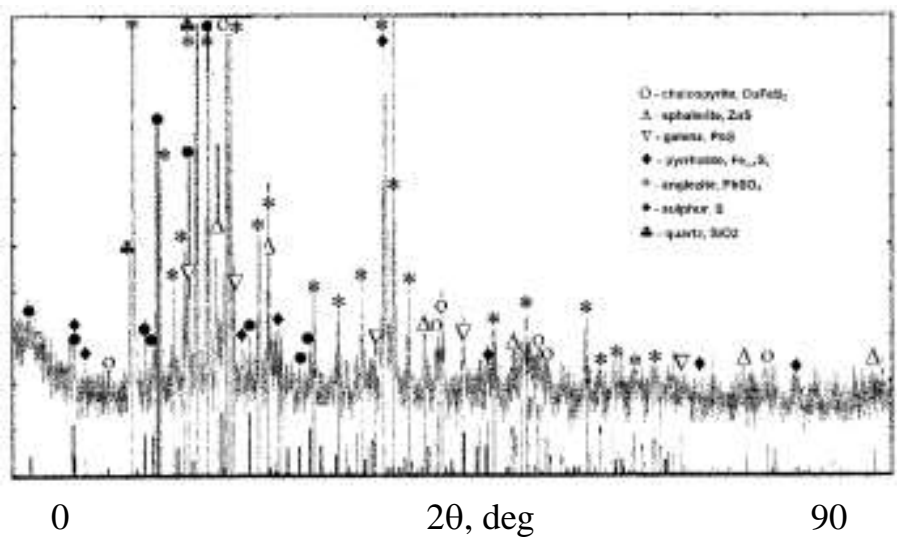

Figure 7 - X-ray diffraction (XRD) analysis of the solid residual after the leaching: $t=90^{\circ} \mathrm{C}, \tau=240 \mathrm{~min}, S: L=1: 5$, the starting concentration of $\mathrm{H}_{2} \mathrm{SO}_{4}=225 \mathrm{~g} / \mathrm{dm}^{3}, \mathrm{NaNO}_{3}$ content $30 \%$ above the stoichiometrically needed, stirring speed 300r/min [20]

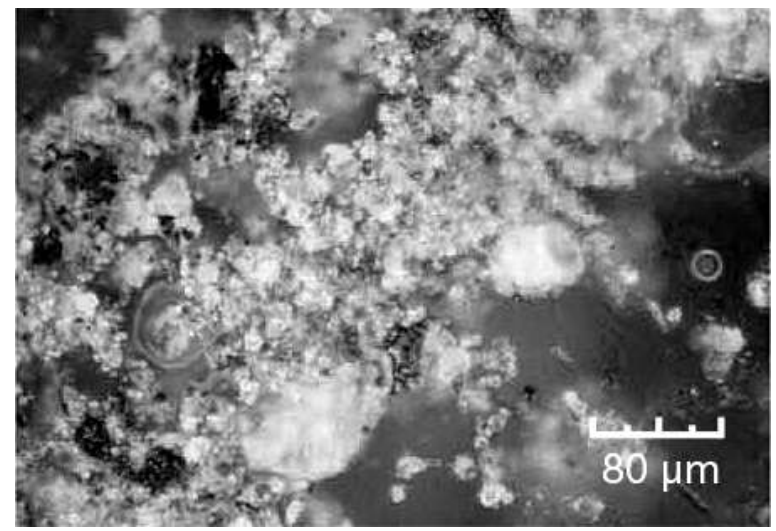

Figure 8 - Microphotograph of the solid residual after leaching (X Nicols, in oil): $t=90^{\circ} \mathrm{C}, \tau=240 \mathrm{~min}, \mathrm{~S}: L=1: 5$, the starting concentration of $\mathrm{H}_{2} \mathrm{SO}_{4}=225 \mathrm{~g} / \mathrm{dm}^{3}, \mathrm{NaNO}_{3}$ content $30 \%$ above the stoichiometrically needed, stirring speed 300r/min 
Microphotographs were taken on a prepared sample of the solid residuals after the leaching process for detection of the present phases. A microphotograph of a selected sample is shown in Fig. 8. For the reason of better phases recognition, the cedar oil was used.

The presence of sulphur and greater amount of anglesite, which shines milky white, is evident in Fig. 8 , and corroded chalcopyrite and pyrrhotite are situated next to the right figure's margin. Thermogram of the solid residual after leaching obtained at a heating rate of $10^{\circ} \mathrm{C} / \mathrm{min}$ in air and shown in Figure 9.

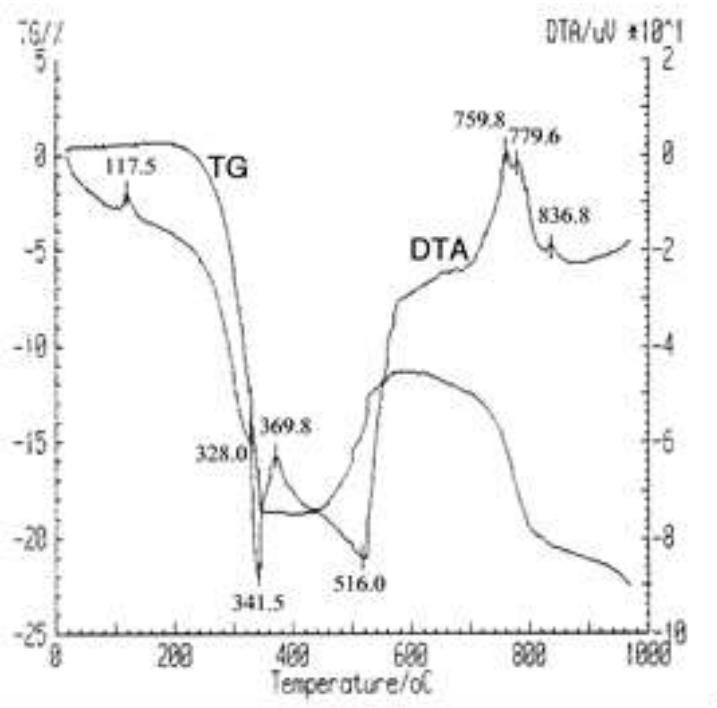

Figure 9 - DTA/TG analysis of polymetallic concentrate

When the sample is heated, an endothermic peak characteristic of elemental sulfur is observed at a temperature of $118^{\circ} \mathrm{C}$. After that, there is a large loss of mass in the range of $250-350^{\circ} \mathrm{C}$, which is a consequence of the oxidation of a large amount of sulfur to $\mathrm{SO}_{2}$. The increase in mass followed by exo-thermic effects takes place in the range of $350-600^{\circ} \mathrm{C}$ and is much smaller than the increase in mass in polymetallic concentrate, which indicates the presence of a small amount of unleaded sulfides. The mass loss above $700^{\circ} \mathrm{C}$ is the result of the dissociation of the present sulphates (mainly anglesites) and is much sma-ller in relation to the analogous mass loss in concen-trates before leaching.

\section{CONCLUSION}

Based on the choosen leaching chemism of the polymetallic sulphide $\mathrm{Zn}-\mathrm{Pb}-\mathrm{Cu}$ concentrate and its thermodynamical analysis, the assumed chemical reactions mechanism for zinc, copper and iron leaching is confirmed.

The phases detection in both, the starting concentrate and the products after the leaching process with
$\mathrm{H}_{2} \mathrm{SO}_{4}$ and $\mathrm{NaNO}_{3}$, were performed for better understanding of the chemical reactions that took place in the system.

The presence of the anglesite, elemental sulphur, gangue and unleached sulphide minerals, was registered using X-ray diffraction (XRD) analysis of the solid residual. This fact points out that leaching product of any sulphide mineral is elemental sulphur, which does not oxidize to sulphate in the temperature range $\left(20-90^{\circ} \mathrm{C}\right)$ and the time interval $(60-240 \mathrm{~min})$.

After the leaching process, copper and zinc are in the form of copper(II) sulphate and zinc(II) sulphate. Iron is being oxidized to form iron(III) sulphate, which then acts as a leaching agent for the present sulphide minerals, and at the same time become reduced to iron(II) sulphate. Lead from the galena reacts to form the lead sulphate (anglesite), which is insoluble and remains in the precipitate.

Detailed mineralogical investigations indicate a po-lymetallic concentrate complexity and explain weak leaching effect of suplhide minerals in the final leaching stage. The main reasons for that are:

- elemental sulphur and anglesite, formed during the process and precipitate at the grain boundaries, fine grained mineral structure and complex mutual inter-growth of chalcopyrite, sphalerite, galena and pyrrho-tite (inclusion, impregnation, simple and complex in-tergrowth),

- complex adhered beneficial suplhide minerals with gangue minerals (predominantly quartz).

The accomplished leaching degrees under the given conditions (temperature of $90^{\circ} \mathrm{C}$, time of 4 hours, phase ratio $\mathrm{S}: \mathrm{L}=1: 5$, the starting $\mathrm{H}_{2} \mathrm{SO}_{4}$ concentration of $225 \mathrm{~g} / \mathrm{dm}^{3}$, with sodium nitrate addition in the content of $30 \%$ above the stoichiometric needed) are as follow: $\mathrm{Zn}-89.25 \%, \mathrm{Cu}-73.08 \%$ and $\mathrm{Fe}-70.80 \%$.

\section{ACKNOWLEDGEMENTS}

The authors are grateful to the Ministry of Education, Science and Technological Development of the Republic of Serbia (Contract number: 451-03-9/202114/200023) for the financial support.

\section{REFERENCES}

[1] Sokić M, Radosavljević S, Marković B, Matković V., Štrbac N, Kamberović Ž, Živković D, Influence of chalcopyrite structure on their leaching by sodium nitrate in sulphuric acid, Metallurgical and Materials Engineering, Vol. 20, No. 1, pp. 53-60, 2014.

[2] Vračar R, Šaljić L, Sokić M, Matković V, Radosavljević S, Chemical-Technological Processing of the Complex Barite-Sulphide Ore, Scandinavian journal of metallurgy, Vol. 32, pp. 289-295, 2003. 
[3] Aydogan S, Ucar G, Canbazoglu M. Dissolution kinetics of chalcopyrite in acidic potassium dichromate solution. Hydrometallurgy, Vol. 81, pp. 45-51, 2006.

[4] Antonijević M, Janković Z, Dimitrijević M, Kinetics of chalcopyrite dissolution by hydrogen peroxide in sulphuric acid. Hydrometallurgy, Vol. 73, pp. 329334, 2004.

[5] Hourn M. M, Turner D. W, Holzberger I. R, Atmospheric Mineral Leaching Process, US Patent 5, 993, $635,1999$.

[6] Cordoba E. M, Munoz J. A, Blazquez M. L, Gonzalez F, Ballester A, Leaching of chalcopyrite with ferric iron: Part I: general aspects. Hydrometallurgy, Vol. 93, pp. 81-87, 2008.

[7] Sokić M, Matković V, Marković B, Manojlović V, Štrbac N, Živković D, Kamberović Ž, Complex sulphide-barite ore leaching in ferric chloride solution, Metallurgical and Materials Engineering, Vol. 22, pp. 81-89, 2016.

[8] Bogdanović G, Petrović S, Sokić M, Antonijević M, Chalcopyrite leaching in acid media: a review, Metallurgical and Materials Engineering, Vol. 26, pp. 177-198, 2020.

[9] Nikoloski A. N, O'Malley G. P, The acidic ferric sulfate leaching of primary copper sulphides under recycle solution conditions observed in heap leaching. Part 1. Effect of standard conditions. Hydrometallurgy, Vol. 178, pp. 231-239, 2018.

[10]Neira A, Pizarro D, Quezada V, Velásquez-Yévenes L, Pretreatment of Copper Sulphide Ores Prior to Heap Leaching: A Review, Metals, Vol. 11, No. 1067, 2021.

[11]Wang J, Faraji F, Ghahreman. Effect of Ultrasound on the Oxidative Copper Leaching from Chalcopyrite in Acidic Ferric Sulfate Media, Minerals, Vol. 10, No. 633, 2020.

[12]Anon, New copper process from Cyprus is billed as „technological breakthrough“. Engineering and $\mathrm{Mi}$ ning Journal, Vol. 178, No. 33, 1977.

[13]Torres C. M, Ghorbani Y, Hernández P. C, Justel F. J, Aravena M. I, Herreros O. O, Cupric and Chloride Ions: Leaching of Chalcopyrite Concentrate with Low Chloride Concentration Media, Minerals, Vol. 9, No. 639, 2019.

[14]Miller P. C, Winby R, The potential commercia-lization of bioleaching for the treatment of chalcopyrite ores and concentrates, Bactech Australia Limited, Bemont: WA, Australia, 2006.
[15]Dew D, Batty J, Biotechnology in mining. Development of the BIOCOP ${ }^{\mathrm{TM}}$ Process. Short Course Lecture. Hydro 2003 Short Course. Montreal: CIM, 2003.

[16]Pradhan N, Nathsarma K.C, Srinivasa Rao K, Sukla L. B, Mishra B. K, Heap bioleaching of chalcopyrite: a review, Minerals Engineering Vol. 21, pp. 355$365,2008$.

[17]Zhang R, Sun C, Kou J, Zhao H, Wei D, Xing Y, Enhancing the Leaching of Chalcopyrite Using Acidithiobacillus ferrooxidans under the Induction of Surfactant Triton X-100, Minerals, Vol. 9, No. 11, 2019.

[18]McDonald R. G, Muir D. M, Pressure oxidation leaching of chalcopyrite. Part I. Comparison of high and low temperature reaction kinetics and products, $\mathrm{Hy}$ drometallurgy, Vol. 86, pp. 191-205, 2007.

[19]Cháidez J, Parga J, Valenzuela J, Carrillo R, Almaguer I, Leaching chalcopyrite concentrate with oxygen and sulfuric acid using a low-pressure reactor, Metals, Vol. 9, No. 189, 2019.

[20]Sokić M, Marković B, Matković V, Živković D, Štrbac N, Stojanović J, Kinetics and mechanism of sphalerite leaching by sodium nitrate in sulphuric acid solution, Journal of mining and metallurgy Section B: Metallurgy, Vol. 48, pp. 185-195, 2012.

[21]Sokić M, Marković B, Živković D, Kinetics of chalcopyrite leaching by sodium nitrate in sulphuric acid, Hydrometallurgy, Vol. 95, pp. 273-279, 2009.

[22]Sokić M, Marković B, Stanković S, Kamberović Ž, Štrbac N, Manojlović V, Petronijević N, Kinetics of Chalcopyrite Leaching by Hydrogen Peroxide in Sulfuric Acid, Metals Vol. 9, No. 1173, 2019.

[23]Anderson C. G, Treatment of copper ores and concentrates with industrial nitrogen species catalized pressure laching and non-cyanide precious metal recovery, JOM: The Journal of Minerals, Metals and Materials Society, Vol. 55, No. 4, pp. 32-36, 2003.

[24]Anderson C. G, Krys L. E, Harrison K. D, Treatment of metal bearing mineral material, US Patent 5,096,486, 1992 .

[25]Castellón C. I, Hernández P. C, Velásquez-Yévenes L, Taboada M. E, An Alternative Process for Leaching Chalcopyrite Concentrate in Nitrate-Acid-Seawater Media with Oxidant Recovery, Metals, Vol. 10, No. 518, 2020.

[26]Torres D, Ayala L, Jeldres R. I, Cerecedo-Sáenz E, Salinas-Rodríguez E, Robles P, Toro N, Leaching 
Chalcopyrite with High $\mathrm{MnO}_{2}$ and Chloride Concentrations, Metals, Vol. 10, No. 107, 2020.

[27]Corrans I. J, Angove J. E, Activation of a mineral species, US Patent, 5,232,491, 1993.

[28]Streltsova N, Johnson G. D, Method for the processing of copper minerals, AU Patent 2003204224A1, 2003.

[29]McDonald R. G, Muir D. M, Pressure oxidation leaching of chalcopyrite. Part II. Comparison of medium temperature kinetics and products and effect of chloride ion, Hydrometallurgy, Vol. 86, pp. 206-220, 2007.

[30]Dreisinger D, Marsh J, Dempsey P, The Anglo American Corporation/University of British Columbia (AAC/UBC) chalcopyrite copper hydrometallurgy process. ALTA 2002 Copper 7 Forum (pp. 24). Perth: ALTA Metallurgical Services, Melbourne, 2002.

[31]Kruesi P. R, Allen E. S, Lake J. L, Cymet processhydrometallurgical coversion of base-metal sulphides to pure metals, CIM Bulletin, Vol. 66, pp. 81-87, 1973.

[32]Jones D. L, CESL copper process. ALTA 1996 Copper Forum (pp. 24). Brisbane: ALTA Metallurgical Services, Melbourne, 1996.

[33]Kofluk D. K, Collins M. J, Hydrometallurgical process for the extraction of copper from sulphidic concentrates, U.S. Patent 5,730,776, 1998.

[34]Stiksma J, Collins M. J, Holloway P, Masters I. M, Desroches G.J., Process development studies by Dynatec for the pressure leaching of HBMS copper sulfide concentrates, CIM Bulletin, Vol. 93, pp. 118$123,2000$.

[35]Demarthe J. M, Gandon L, Georgeaux A, A new hydrometallurgical process for copper. In J. Yannopoulos and J. Agarwal, (Eds.). Extractive metallurgy of copper (pp. 825-888). New York: AIME, 1976.

[36]Dreisinger D, Richmond G, Hess F, Lancaster T, The competitive position of the Mt. Gordon copper process in the copper industry. ALTA 2002 Copper 7 Forum (pp. 14). Perth: ALTA Metallurgical Services, Melbourne, 2002.

[37]Richmond G. D, Dreisinger D. B, Processing of copper sulfide ores by autoclave leaching followed by extraction and electtrowinning, Australian Patent 749257, 2002.

[38]Van Weert G, Fair K. J, Schneider J. C, The NITROX process for treating gold bearing arsenopyrites. Presented at 116th Annu. TMS/AIME Meet. Denver, 1986.

[39]Ackerman J. B, The Sunshine Mining Company's Silver Refinery. Fourth Western Regional Confere- nce Precious Metals and the Environment (pp. 219235). Allentown: AIME, 1990.

[40]Fleming C. A, Dreisinger D. B, O'Kane P. T, Oxidative Presure Leach Recovery Using Halide Ions, U.S. Patent 6,315,812, 2001.

[41]Baxter K, Dreisinger D. B, Pratt G, The Sepon copper project: development of a flowsheet. In C.A. Young (Ed.), Hydro 2003 (pp. 545-553). Warrendale: TMS, 2003.

[42]Swinkels G. M, Berezowsky R. M. G. S, The Sherritt-Cominco copper process Part I: The Process. CIM Bulletin, Vol. 71, pp. 105-121, 1978.

[43]Bolton G. L, Zubrycki N, Veltman H, Pressure leaching process for complex zinc-lead concentrates. In J. Laskowski (Ed.), International mineral processing Congress (pp. 581-607) Warsaw, 1979.

[44]Marsden J, Brewer B, Hazen N, Copper concentrate leaching developments by Phelps Dodge Corpo-ration, Hydro 2003 (pp. 1487-1502). Warrendale: TMS, 2003.

[45]Habashi F, Nitric acid in the hydrometallurgy of sulfides, In B.Mishra, (Ed.), EPD Congress (pp. 25 32). The Minerals, Metals and Materials Society, 1999.

[46]Van Weert G, Fair K. J, Schneider J. C, The NITROX process for treating gold bearing arsenopyrites. Presented at 116th Annu. TMS/AIME Meet. Denver, 1986.

[47]Droppert D. J, Shang Y, The leaching behaviour of nickeliferous pyrrhotite concentrate in hot nitric acid, Hydrometallurgy, Vol. 39, pp. 169-182, 1995.

[48]Anderson C. G, Harrison K. D, Krys L. E, Theoretical considerations of sodium nitrite oxidation and fine grinding in refractory precious metals concentrate pressure leaching. Transactions of the Society for Mining, Metallurgy and Exploration, Vol. 299, pp. 4-11, 1996.

[49]Bredenhann R, Van Vuuren C. P. J, The leaching behaviour of a nickel concentrate in an oxidative sulphuric acid solution, Minerals Engineering, Vol. 12, pp. 687-692, 1999.

[50]Sokić M, Stojanović J, Marković B, Bugarčić M, Štrbac N, Kamberović Ž, Manojlović V, Uticaj strukturno-teksturnih karakteristika sulfidnih mineral na njihovo luženje iz polimetaličnog koncentrata rastvorom natrijum-nitrata i sumporne kiseline, Hemijska industrija, Vol. 71, No. 6, pp. 461-469, 2017.

[51]Akcil A, Ciftci H, Metals recovery from multimetal sulphide concentrates $\left(\mathrm{CuFeS}_{2}-\mathrm{PbS}-\mathrm{ZnS}\right)$ : combi-nation of thermal process and pressure leaching, Internetional Journal of Mineral Processing, Vol. 71, pp. 233-246, 2003. 


\section{REZIME}

\section{LUŽENJE POLIMETALNOG CU-ZN-PB KONCENTRATA NATRIJUM-NITRATOM I SUMPORNOM KISELINOM}

U radu su prikazani i diskutovani rezultati luženja polimetalnog sulfidnog $\mathrm{Cu}$-Zn-Pb koncentrata rastvorom natrijum-nitrata $i$ sumporne kiseline pri atmosferskom pritisku. Prikazan je hemijski $i$ mineraloški sastav polaznog koncentrata i čvrstih ostataka nakon procesa luženja. Hemijske reakcije luženja i mogućnosti njihovog odvijanja analizirane su primenom termodinamičke analize na osnovu izračunatih Gibbsovih energija $i$ analize E-pH dijagrama. Eksperimentalno je analiziran uticaj temperature $i$ vremena na stepen izluženja korisnih metala iz sulfidnog koncentrata. Pokazano je da je moguće dobiti bakar, cink i železo u rastvoru u obliku sulfata, dok olovo u obliku anglesita (PbSO4) ostaje u čvrstom ostatku nakon procesa luženja. Železo se oksidiše u Fe (III) -sulfat, koji učestvuje u luženju sulfidnih minerala i prelazi u Fe (II) -sulfat.

Ključne reči: polimetalni $\mathrm{Cu}$-Zn-Pb koncentrat, luženje, natrijum-nitrat, sumporna kiselina 